\title{
総合健診における胆のうポリープ保有者について
}

\begin{tabular}{|c|c|c|c|c|c|}
\hline ○吉田 & 友彦 & 福田 & 定男 & 吉益 & 均 \\
\hline 岩崎 & 至利 & 野呂 & 光子 & 初芝 & 澄雄 \\
\hline
\end{tabular}

昭和 61 年 1 月から 12 月の間に，当健部センターを受 診し腹部超音波検査 (US) が施行された 8,648 名 (男性 6, 386 名 19 80 歳, 女性 2,262 名 10 82 歳) を対象之 し, 胆のうの隆起性病変の頻度, 大きさや数等に関する US 所見の検討を行った。頻度は全体では $0.9 \%$ あっ た。性別では男性が $1.0 \%$ ，女性が $0.5 \%$ であった。大 きさに関しては $5 \mathrm{~mm}$ 以下が $69.1 \%$ と最も多く認めら れたが，むしろその臨床上の取り扱い上，種々の問題を 有してくる $6 \mathrm{~mm}$ 以上が約 $30 \%$ あったてとが, 注目 されるべきであろう。数に関しては単発が $84.0 \%, 2$ 個 $12.3 \%, 3$ 個以上 $3.7 \%$ であった。輝度については肝よ りも高輝度であったあのが $82.7 \%$ と圧倒的に多数を占 めたが，一般的に高頻度とされるコレステロールポリー プは高輝度を呈する場合が多いととを考慮すると，充分
に納得しうる結果といえる。

胆道造影 (DIC) を施行し得た 38 症例については, 病 変の描出能を US と対比したが, DIC の所見とUS の 所見が一致したのは，わずかに $26.3 \%$ にすぎなかった US で $4 \mathrm{~mm}$ 以下の病変の過半数が DIC で無所見であ ったととが原因と考えられた。胆のうの隆起性病変の検 出には US が優れているとされるが，乙のととを裏付 ける結果といえよう。しかしながら, 胆のうの隆起性病 変の質的診断には US をはじめ各種の画像診断法を駆 使してもなお難渋する場合む少なくなく，演者らはこの ような症例に対し経皮経肝的胆のう内視鏡検査および生 検を施行している。極めて有用な質的晾断法を考えてお り，本法を施行した症例む併せて供覧した。

\section{A Study of PolyPoid Leseon of Goll Bladder in AMHTS}

東京医科大学病院・東実総合健診センター 